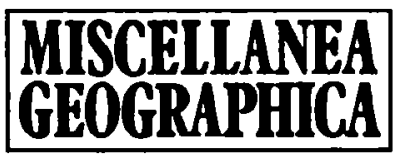

WARSZAWA 1994 Vol. 6

Jerzy Boryczka, Bogumił Wicik

\title{
RECORD OF HOLOCENE CLIMATIC CYCLES IN LAKE SEDIMENTS IN CENTRAL POLAND
}

\section{INTRODUCTION}

The purpose of the paper is to identify astronomical causes of Holocene climatic fluctuations. Analogous cycles - lasting several hundred or several thousand years - of contents of organic substance in lacustrine sediments and of the parameters of the Solar System were ascertained.

The statistical analysis of chronological sequences of accumulation of bottom sediments in the following lakes was made: Wikaryjskie, Gościąz and Swięte, situated in the Gostyń - Włoclawek Lake District in Poland.

A cylinder-shaped sample of the sediment $3.80 \mathrm{~m}$ in length was collected from Lake Wikaryjskie, and the content of organic substance (in percent) in 20-mm small layers $(n=195)$ was determined. Below the sediment layer peat was found which was dated to $10,360 \pm 200$ years by use of the radiocarbon method (Boryczka, Wicik 1983; Fig.1A).

The bottom sediments of Lake Gościąż are laminated and the annual increments are well seen. In a cylinder-shaped sample of $16 \mathrm{~m}$ in length (core GO) $n=1230$ ten-year increments were calculated. In this case determination of absolute calendar time calculation was not difficult (Boryczka, Wicik 1989; Fig.1B).

From Lake Swiete a sediment sample of $13.20 \mathrm{~m}$ in thickness was collected and the percent content of organic substance every $6 \mathrm{~cm}(\mathrm{n}=221)$ and of density of sediments $\left(\mathrm{g} / \mathrm{cm}^{3}\right)$ every $3 \mathrm{~cm}(\mathrm{n}=422)$ was determined. The axis of time was drawn on the basis of five datings by the radiocarbon method: $4.0-4.1 \mathrm{~m}-2840 \pm 100$ years, $8.05-8.14-4510 \pm 110$ years, $9.65-9.75 \mathrm{~m}-7010 \pm 90$ years, $11.86-11.88 \mathrm{~m}-10,060 \pm 140$ years and $12.22-12.27 \mathrm{~m}-12,400 \pm 170$ years, taking into account variable compression of sediments (Figs. 1C, 1D).

Changes occurring in the Solar System 20,000 years ago were shown by

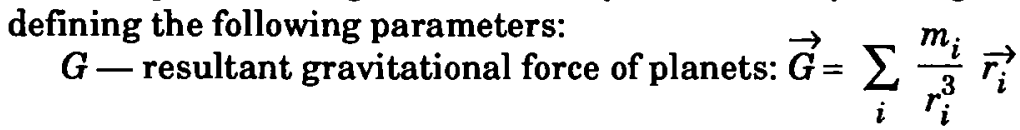



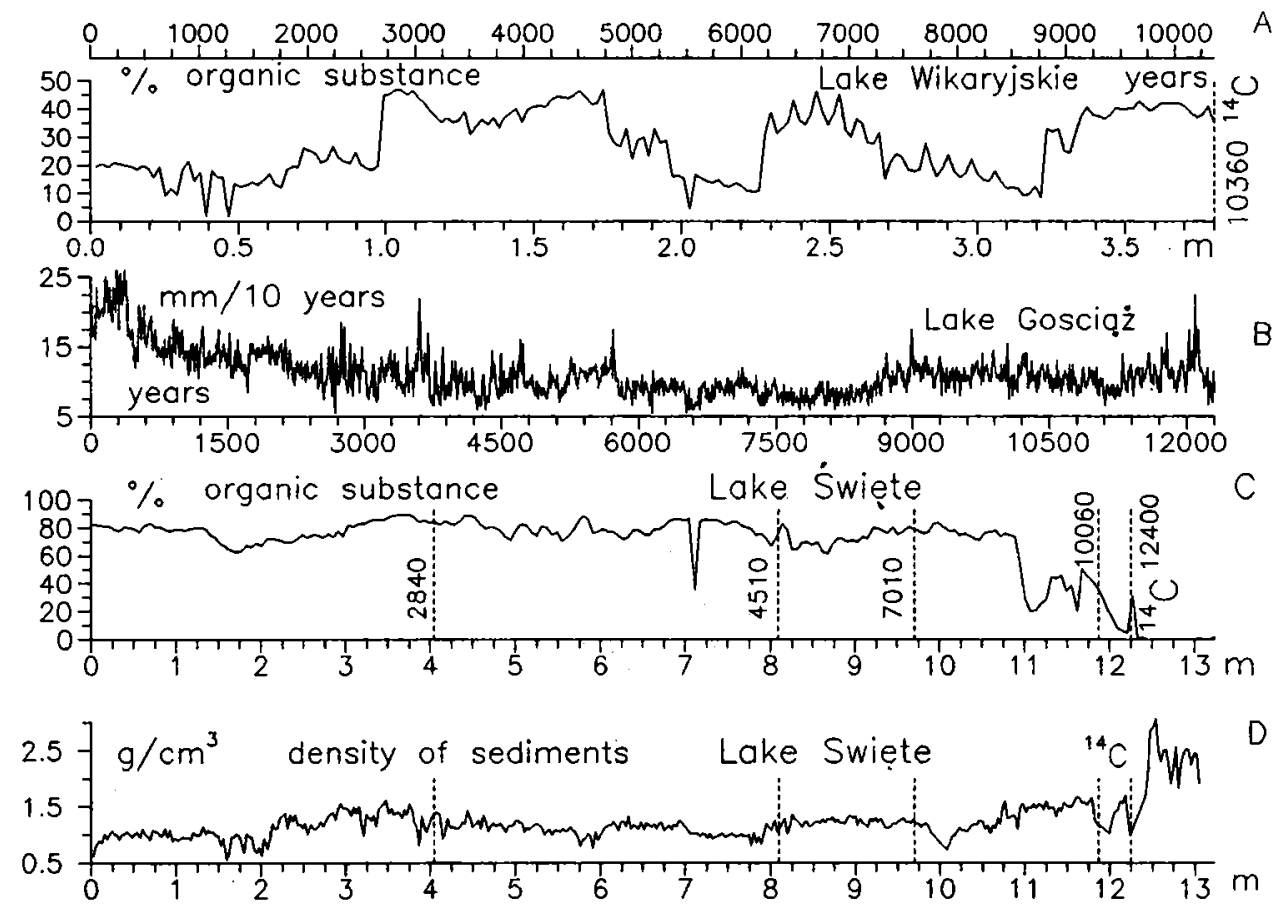

Fig.1. Chronological sequences of accumulation of bottom sediments in Polish lakes: Wikaryjskie, Gościqu̇, Swięte (organic substance, 10-year increments, dengity)

$\Delta G$ - resultant of tidal force on the Sun (towards the direction of the mass centre): $\Delta \vec{G}=\frac{\vec{s}}{s} \cdot \sum_{i} \frac{m_{i}}{r_{i}^{4}} \overrightarrow{r_{i}}$

$J$ - total momentum of planets : $\vec{J}=\sum m_{i} \frac{d \overrightarrow{r_{i}}}{d t} \times \overrightarrow{r_{i}}, A U^{2} /$ month

$\cos \Gamma-$ cosine of angle between vector radii of the mass centre $\vec{s}$ and geometrical centre $\vec{S}$ of the Solar System, $\vec{s}=\frac{1}{M} \sum_{i} m_{i} \overrightarrow{r_{i}}, \vec{S}=\frac{1}{9} \sum_{i} \overrightarrow{r_{i}}(M-$ mass of Solar System $)$, where $m_{i}, \overrightarrow{r_{i}}-$ mass and vector radius of the $i$ th planet.

Heliocentrical ecliptic coordinates from before 20,000 years were determined taking into account secular changes of parameters of their orbits, i.e. polynomials published by A.P.Reznikov (1982).

The true cycles (spectra of oscillation) were established by the Boryczka method of " regression sinusoids"

$$
y=a+b \sin \left(\frac{2 \pi}{\Theta} t+c\right)
$$

changing period $\Theta$ every 1 or prescribing its values $\Theta_{1}, \ldots, \Theta_{n}$ 
Forecasts of climatic changes were made on the basis of the function of time trend

$$
y=a_{o}+\sum_{j} b_{j} \sin \left(\frac{2 \pi}{\Theta_{j}} t+c_{j}\right),
$$

where $\theta_{j}$ are discovered periods in the spectrum of oscillation

True cycles $\theta_{\mathrm{j}}$ are local maxima of the spectrum of oscillation $b_{1}, \ldots, b_{n}$ Amplitudes $b_{1}, \ldots, b_{k}$ were verified by the Fisher-Snedecor test of $n_{1}=2$ and $n_{2}=n-3$ degrees of freedom.

\section{SYNCHRONIC CHARACTER OF CYCLES OF ORGANIC SUBSTANCE AND OF PARAMETERS OF THE SOLAR SYSTEM}

The spectra of oscillation of sedimentological and astronomical variables were shown in Figures 2 and 3. The true cycles of sedimentological variables in Lake Swięte are as follows:

\begin{tabular}{|c|c|c|c|c|c|c|c|}
\hline \multicolumn{5}{|c|}{ organic substance (\%) } & \multicolumn{3}{c|}{ density of sediments $\left(\mathrm{g}^{\prime} \mathrm{cm}^{3}\right)$} \\
\hline$\Theta$ & $b$ & $c$ & $R$ & $\Theta$ & $b$ & $c$ & $R$ \\
\hline 120 & 5.87 & -2.58 & 0.167 & 60 & 0.069 & 0.65 & 0.081 \\
190 & 3.27 & -2.91 & 0.167 & 270 & 0.032 & 2.91 & 0.061 \\
370 & 3.67 & -1.21 & 0.105 & 360 & 0.031 & $-2 . .25$ & 0.064 \\
530 & 1.54 & -2.15 & 0.044 & 540 & 0.037 & -2.59 & 0.077 \\
560 & 1.36 & -0.43 & 0.039 & 590 & 0.041 & -2.44 & 0.087 \\
690 & 2.21 & -0.26 & 0.062 & 710 & 0.054 & -1.46 & 0.113 \\
770 & 2.24 & 0.83 & 0.063 & 760 & 0.061 & 0.71 & 0.128 \\
870 & 2.51 & 2.38 & 0.071 & 820 & 0.083 & 2.60 & 0.174 \\
1050 & 2.61 & 1.53 & 0.074 & 1010 & 0.085 & 2.90 & 0.178 \\
1190 & 2.39 & -0.78 & 0.067 & 1110 & 0.058 & -2.19 & 0.122 \\
1310 & 4.05 & -0.40 & 0.116 & 1340 & 0.036 & -2.31 & 0.075 \\
1600 & 3.70 & -0.98 & 0.105 & 1590 & 0.054 & -0.66 & 0.113 \\
2020 & 4.99 & 0.48 & 0.145 & 1920 & 0.059 & 1.72 & 0.121 \\
2450 & 4.60 & -0.05 & 0.134 & 2250 & 0.122 & 1.41 & 0.255 \\
2940 & 4.18 & 0.80 & 0.118 & 2780 & 0.162 & 2.58 & 0.324 \\
4020 & 14.00 & 2.47 & 0.393 & 3620 & 0.248 & -2.57 & 0.534 \\
7350 & 11.60 & -0.50 & 0.306 & 5500 & 0.168 & -1.37 & 0.325 \\
& & & & 7860 & 0.123 & -2.98 & 0.240 \\
& & & & & & & \\
\hline
\end{tabular}

where $R$ is the coefficient of multiple correlation $\left(R_{0.05}=0.144, R_{0.10}=\right.$ 0.104).

Statistically significant cycles at the level of confidence $90 \%$ and slightly lower are underlined. This testifies to the reliability of the measurements, dating as well as statistical analyses. 

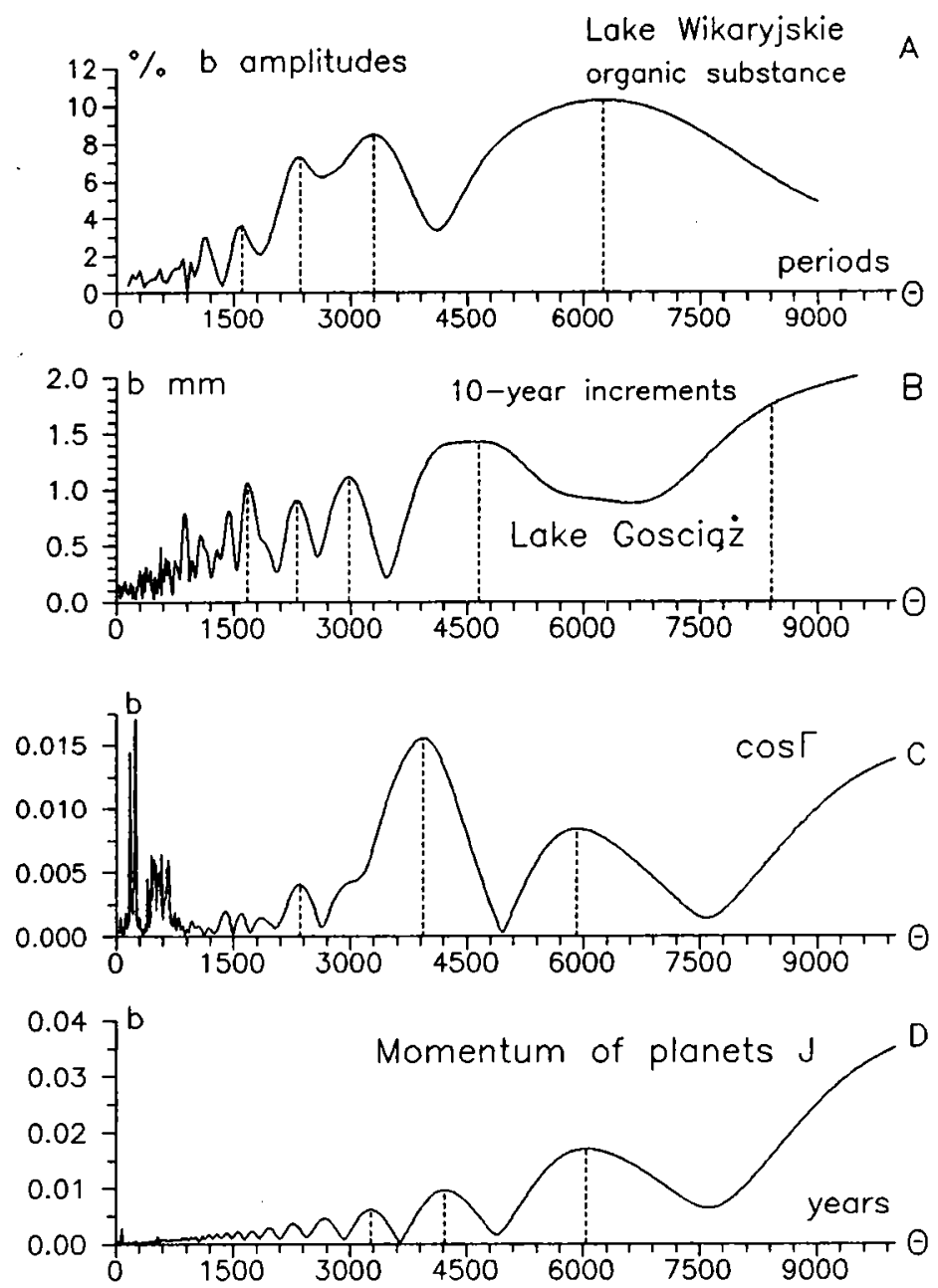

Fig.2. Spectra of oscillation of sedimentological (Lakes Wikaryjskie and Gościąz) and astronomical variables (total momentum of planets $J$, cos $\Gamma$ )

Of great cognitive value for the explanation of causes of Holocene climatic variations is the discovery of astronomical variables in the spectra of oscillation: resultant gravitational force of planets $(G)$, resultant of tidal force on the Sun $(\Delta G)$, total momentum of planets $(J)$, and $\cos \Gamma$ of the same cycles as those found in the spectra of oscillation of sedimentological variables: Lake Swięte 1 - organic substance, Lake Swięte 2-density of sediments, Lake Wikaryjskie - organic substance, Lake Gościąz - 10-year increments of thickness of sediments. Similarity of the spectra of oscillation implies the hypothesis about the astronomical causes of Holocene climatic variations. This testifies to the effect of changes occurring in the Solar Sys- 
tem on accumulation of organic substance in lake sediments, which are correlated with climate (air temperature and precipitation).

Here is the comparison of the true cycles of sedimentological and astronomical variables:

\begin{tabular}{|c|c|c|c|c|c|c|c|}
\hline Sw.1 & Sw.2 & Wik. & Gos. & $\boldsymbol{G}$ & $\Delta G$ & $J$ & $\cos \Gamma$ \\
\hline 120 & - & 200 & . & 180 & 170 & 80 & 170 \\
\hline 370 & 360 & 300 & 300 & 380 & 310 & . & 250 \\
\hline 530 & 590 & 550 & 560 & 480 & 510 & 530 & 570 \\
\hline 870 & 820 & 850 & 870 & 940 & 930 & . & 800 \\
\hline 1050 & 1010 & 950 & 970 & 1010 & 1120 & 110 & 1050 \\
\hline 1310 & 1110 & 1150 & 1280 & 1370 & 1480 & 1410 & 1400 \\
\hline $1600 / 2020$ & $\underline{1590}$ & $\underline{1600}$ & 1680 & $\underline{1650}$ & $\underline{1670}$ & $\underline{1560}$ & $\underline{1600}$ \\
\hline 2450 & $\overline{2250}$ & $\overline{2350}$ & 2310 & $\overline{2520}$ & $\overline{2280}$ & $\overline{2290}$ & $\overline{2350}$ \\
\hline 2940 & $\overline{2780}$ & $\overline{3300}$ & $\overline{2970}$ & $\overline{3040}$ & 2960 & $\overline{3270}$ & • \\
\hline 4020 & 3620 & . & . & 3780 & 4000 & 4220 & 3940 \\
\hline . & 5500 & 6150 & 4600 & 5060 & . & 6040 & 5920 \\
\hline 7350 & 7860 & . & . & 7750 & 7730 & . & . \\
\hline
\end{tabular}

Cycles of accumulation of organic substance in sediments of Lake Siwięte of the highest amplitudes are: 2020, 2450, 4020 and 7350 years. The two latter (unknown so far) are strongest ( 4020 years $-R=0.39,7350$ years $-R=0.31$ ).

Two cycles (among Sw.1): 370 and 2450 years occur in the set of 4 cycles of climatic changes: $78,180,400,2400$ years, determined by the oxygen isotope ${ }^{18} \mathrm{O}$ (Johnsen et al., 1970).

The cycle of 2450 (according to the oxygen isotope ${ }^{18} \mathrm{O}-2400$ years) approximates the strongest cycle of the resultant of the effect of gravitational force of planets on the Sun of 2280 years. In all the spectra there occurs the Peterson cycle of 1600 years (of location of planets), whereas the cycle of glacial large-scale climatic processes of 1850 years (Maksimov 1972) - of volcanic activity - does not occur in the spectra of sedimentological variables or the Johnson set. There is a cycle of accumulation of organic substance in the sediments of Lake Swięte which is slightly longer (2020 years).

\section{FORECAST OF CLIMATIC CHANGES ACCORDING TO ACCUMULATION OF ORGANIC SUBSTANCE IN LAKE SEDIMENTS}

Knowing the spectra of oscillation (true cycles) of contents of organic substance (in percent) in the bottom sediments of Lake Swięte and density of sediments (in $\left.\mathrm{g} / \mathrm{cm}^{3}\right)$, time trends were determined $(y=f(t))$. For example, the time trend of organic substance $(y)$ in sediments of that lake, taking into account 15 strongest cycles, is expressed by the following formula: 


$$
\begin{aligned}
& y=64.47+4.007 \sin (0.5236 t-2.496)+2.996 \sin (0.3306 t-2.816)+ \\
& +3.318 \sin (0.1696 t-1.176)+0.763 \sin (0.0966 t-1.728)+ \\
& +2.037 \sin (0.0816 t+1.417)+3.489 \sin (0.0722 t-1.819)+ \\
& +3.740 \sin (0.0598 t+1.197)+2.542 \sin (0.0528 t+0.361)+ \\
& +5.337 \sin (0.0478 t-0.083)+4.342 \sin (0.0392 t-1.212)+ \\
& +7.254 \sin (0.0312 t+0.427)+5.378 \sin (0.0256 t-0.280)+ \\
& +4.778 \sin (0.0214 t-1.433)+14.150 \sin (0.0156 t+2.661)+ \\
& +12.160 \sin (0.086) \quad-1.401)
\end{aligned}
$$

which is characterized by quite a high precision: correlation coefficient $R=$ $=0.607$, the Fisher-Snedecor test $F=3.693$ (critical value $F_{0.10}=2.0$, arith-
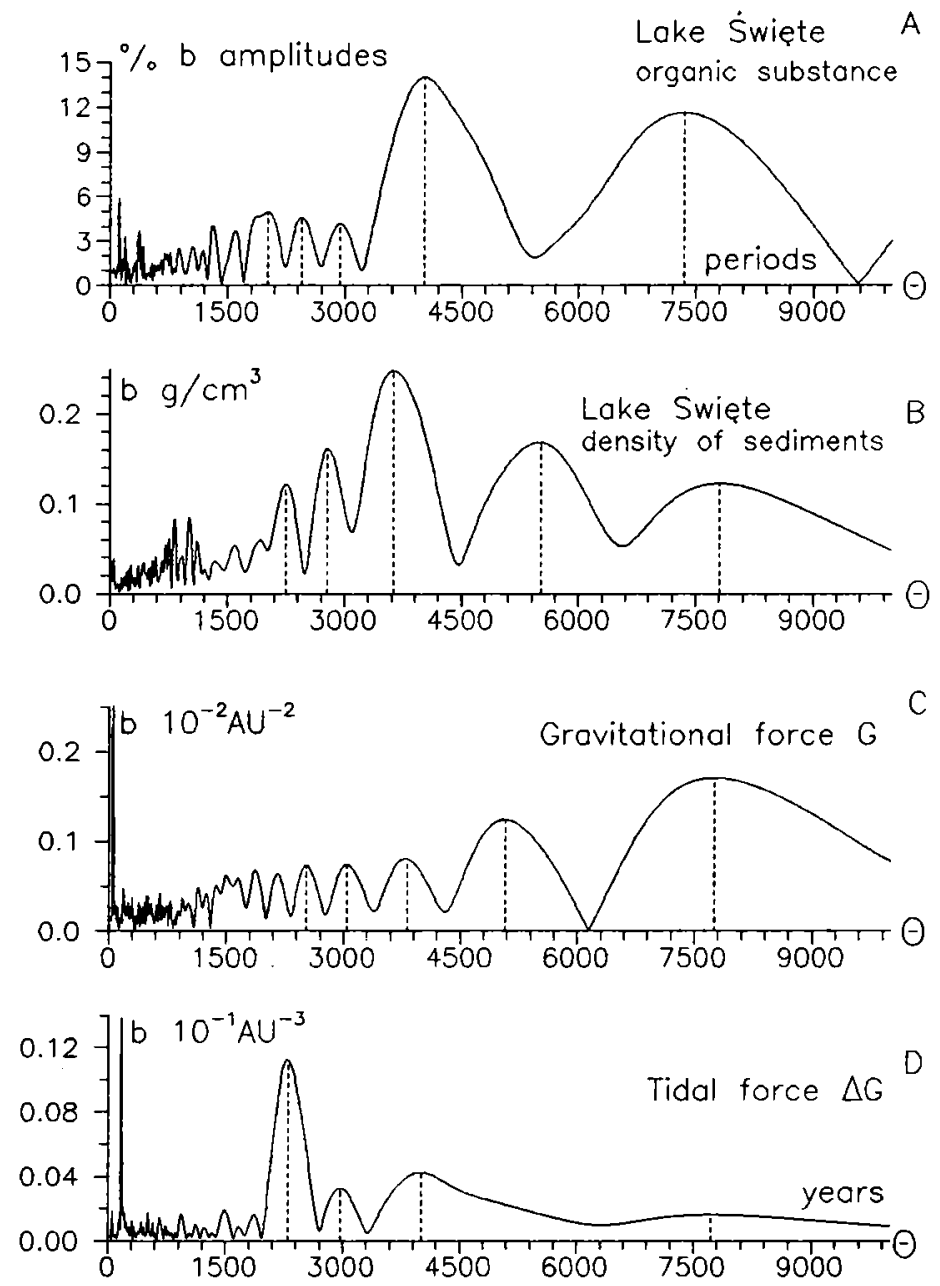

Fig.3. Spectra of oscillation of sedimentological (Lake Swięte) and astronomical variables (resultant of the gravitational force of planets $G$, tidal force on the Sun $\Delta G$ ) 
metic mean $\bar{y}=66.97 \%$, standard deviation $s=24.77 \%$, and standard error $\delta=21.23 \%$.

Curves in Figure 4 show the function of time trends of organic substance (in percent) and density of sediments $\left(\mathrm{g} / \mathrm{cm}^{3}\right)$. The curves consist of three parts: RECONSTRUCTION, APPROXIMATION and FORECAST (negative time). Forecasts (predicted future) in the calendar time calculation are shown in Figures $4 \mathrm{C}$ and $4 \mathrm{D}$.

The minima of organic substance in Lake Swięte (Fig.4A) correspond to Holocene cooling of climate, while maxima - to warming up. Secular extreme values of the curve (minima and maxima) were compared with the results of investigations in Lake Wikaryjskie and Lake Gościąz (Boryczka, Wicik 1983,1989), as well as with the cooling and warming of climate in Europe and North America (Lake Wisconsin) known from literature:

COOLING OF CLIMATE (dates):

\begin{tabular}{|r|c|c|c|}
\hline L.Święte & L.Wikaryjskie & L.Gością & acc.to others \\
\hline$-18,500$ & & $\begin{array}{l}-17,000, \\
\text { Keree }\end{array}$ & \\
$-17,300$ & & $-12,700$ & \\
$-14,000$ & $-14,700$ & $-11,150$ & \\
$-11,450$ & $-11,750$ & $-10,000$, Mancato, Kary \\
& $-10,200$ & -250 & 8,500, Europa \\
$-9,000$ & $-8,000$ & -5000 & \\
-4930 & -5200 & -4150 & -3900 \\
-3600 & -3400 & -1950 & -2500, Europa \\
& -2450 & -1000 \\
-1200 & -1200 & 1100 & forecast \\
360 & & forecast \\
& 1400 & forecast \\
2630. & 4700 & 4600 & \\
3000 & & & \\
\hline
\end{tabular}

WARMING OF CLIMATE (dates):

\begin{tabular}{|r|c|c|l|}
\hline L.Swięte & L.Wikaryjskie & L.Gościąz & \multicolumn{1}{|c|}{ acc.to others } \\
\hline$-18,350$ & & & \\
$-15,700$ & & & \\
$-14,830$ & $-13,700$ & $-12,100$ & $-11,400 \pm 350$, Two Creeks \\
$-12,200$ & - & $-9,000$ & $-10,800 \pm 580$, Alleröd \\
$-10,300$ & $-11,000$ & $-7,700$ & \\
-8300 & -9500 & $-5400,-4700$ & -4000 optimum of climate \\
-4400 & $-6300,-4100$ & $-3650,-1900$ & (absolute maximum \\
-2400 & $-2900,-1650$ & & in North America) \\
& & 2700 & forecast \\
1000 & 600,2600 & 4150 & forecast \\
4600 & - & \multicolumn{2}{|l}{} \\
\hline
\end{tabular}



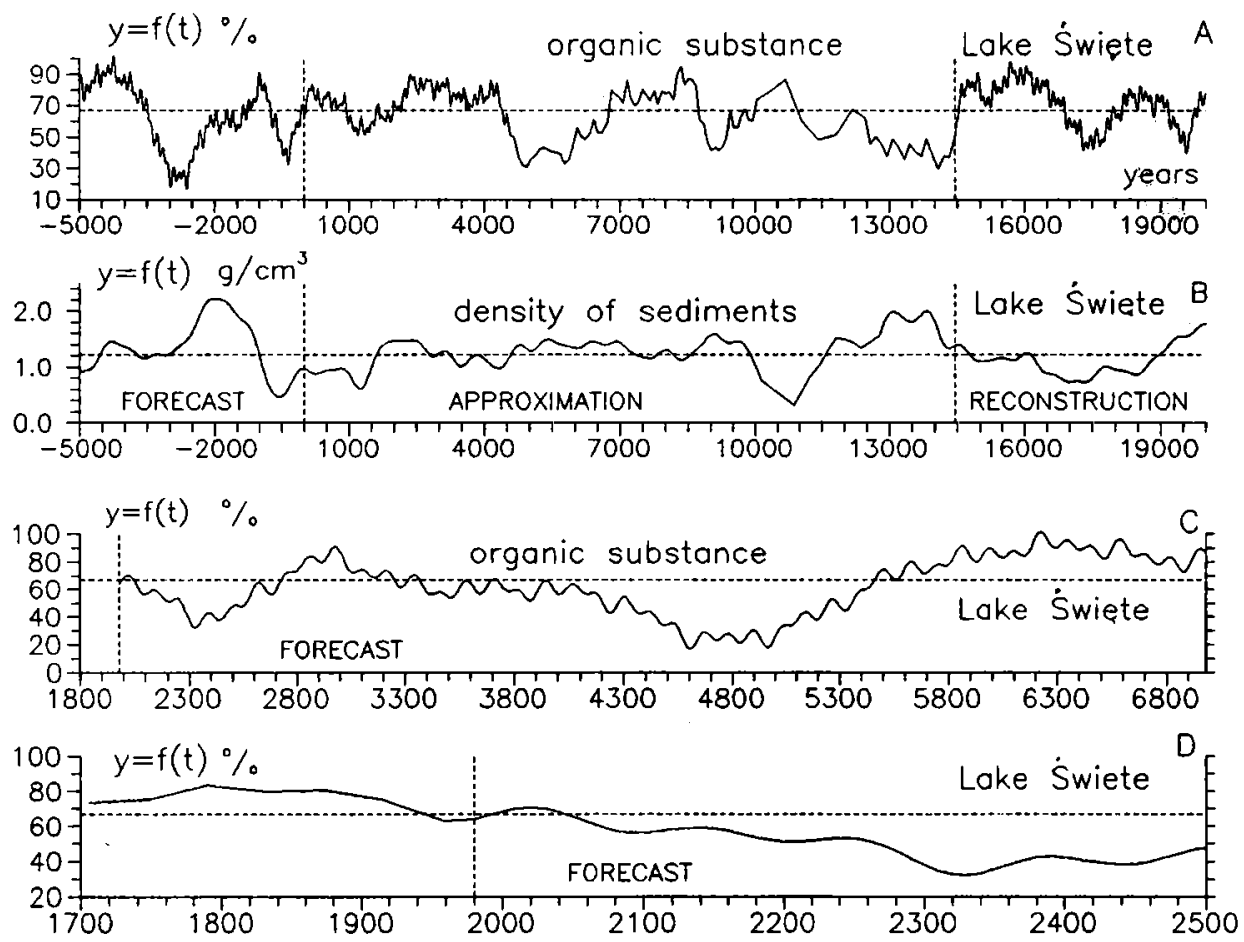

Fig.4. Reconstruction-approximation-forecast of accumulation of organic substance in sediments of Lake Swięte: 20,000 years ago and in 5,000 years. Curves C,D - according to the calendar time calculation

The warming of -6300 and -5400 years ago coincides with the minimum of seismic activity which occurred 5800 years ago.

According to the content of organic substance in sediments of Lake Swięte, the nearest cooling of climate will occur in 360 years, and the subsequent one in 2630 years. These are only extremal values of the curves of the air temperature changes from before 20,000 years and in 5000 years (zero of the time axis $t$ occurred in the year 1990 in which a sediment sample was collected below the bottom of Lake Swięte).

The curve predicting the contents of organic substance in sediments of Lake Swiete in the years $1980-2500$ is below the mean $\bar{y}=66.97 \%$. Thus, we may predict a considerable cooling of climate in the coming 500 years (the greatest one is likely to occur between 2300 and 2400; see Fig.4D). 


\section{REFERENCES}

Boryczka J., Wicik B., 1983, "Holoceńskie cykle klimatu w środkowej Polsce na podstawie statystycznej analizy osadów jeziornych" (Holocene climatic cycles in Central Poland on the basis of statistical analysis of lake sediments), Przeglad Geofizyczny, Vol.XXVIII, Nos.3-4.

B oryczka J., Wicik B., 1989, "Holocene climatic changes in the light of statistical analysis of laminated sediments from Lake Gościąz", Zeszyty Naukowe Politechniki Ślqskiej, Matematyka-Fizyka, No.57, Geochronometria No.5.

Boryczka J., Stopa-Boryczka M., Kicińska B., Żmudzka E., 1992, Atlas wspótzależności parametrów meteorologicznych i geograficznych w Polsce, cz.VII. Zmiany wiekowe klimatu Polski (Atlas of Correlation of Meteorological and Geographical Parameters in Poland, Part VII. Secular changes of Poland's climate), Warszawa.

Boryczka J., 1993, Naturalne $i$ antropogeniczne zmiany klimatu Ziemi $w$ XVII-XXI wieku (Natural and Man-Made Changes of the Earth's Climate in the 17th-21st centuries), Uniwersytet Warszawski WGiSR, Warszawa.

Greaedel T.E., Crutzen P.J., 1993. Atmospheric change and Earth System Perspective, Library of Congress Cataloging - in - Publication Data, W.H. Freeman and Company, New York.

Johnsen S.J., et al., 1970, "Climatic oscillations 1200-2000 A.D.", Nature, No.2\$7, London.

Maksimov E.W., 1972, Problemy oledienenya Ziemli $i$ ritmy $w$ prirodie (Problems of the Earth's cooling and rythms in Nature), Izd.Nauka, Leningrad.

Reznik ov A.P., 1992, Predskazanye iestestvennykh protsesov obukhaiushcheisia sistemoi (Prediction of natural processes by a learning system), Novosibirsk. 
